\title{
MEGHANISM OF POTENTIATING ACTION OF EPINEPHRINE ON THIOPENTAL ANESTHESIA
}

\author{
YOSHIO OHMIYA*, HIDEYO OHSHIKA AND KENGO NAKAI \\ Depariment of Pharmacology, Sapporo Medical College, Sapporo \\ Received for publication June 20, 1970
}

A number of papers have been presented in support of the concept that epincphrine potentiates barbiturate anesthesia in experimental animals (1-3). Recently, Mazel et al. (4) reported that epinephrine increased the brain level of barbital above controls and suggested that epinephrine may affect the permeability of the blood-brain barrier as well as other barriers. However, mechanism of the potentiating action of epinephrine on barbiturate anesthesia still remained to be elucidated.

Meanwhile, Ohshika in our laboratory has reported that thiopental bound to plasma albumin can be displaced in vitro by a series of fatty acids (5) and further that anesthetic effect of thiopental was potentiated in rats or mice pretreated with sodium oleate. From a consideration of the results, he suggested the implication of plasma free fatty acids (FFA) in the thiopental anesthesia.

Several studies (6-8) have demonstrated that the pharmacological effect of a highly bound drug may be increased when the drug is displaced from its binding sites by another drug or substance. Solomon et al. (7) reported that many acidic compounds of unrelated chemical structure bound to a common site on the albumin molecule and that, among them, fatty acids were avidly bound to albumin and acted as effective displacers of another acidic drugs from albumin.

The well-known relation of epinephrine to FFA in the movement of the latter in and out of adipose tissue $(9,10)$ and the implication of epinephrine in barbiturate anesthesia suggested a trial of epinephrine under conditions similar those described for fatty acids.

The purpose of this investigation was to study the potentiating effect of epinephrine, and by comparison, sodium oleate on the thiopental anesthesia. The data presented here indicate that potentiation of thiopental anesthesia may be due to an increased penetration of thiopental into the brain. In addition, observations are also presented indicating that epinephrine may potentiate thiopental anesthesia through its lipolytic action.

\section{MATERIALS AND METHODS}

Animals: Male mice of dd strain weighing 20-30 $\mathrm{g}$ and male rats of Wistar strain weighing 200-300 $\mathrm{g}$ were used.

大宮 樹界・大鹿 英世・中井 健五

* The portion of this work contributed by Yoshio Oнмгул is from a thesis submitted by him in partial fulfilment of the requirements for the M.D. degree of the Sapporo Medical College. 
Sleeping lime: Experiments were performed in the room in which the animals were kept at temperature of $22-24^{\circ} \mathrm{C}$. The sleeping time was defined as the interval in minutes starting at the point where mice or rats could be placed on their back and lasting until their righting reflex was regaincd.

Determination of brain- and plasma- ${ }^{35}$ S-thiopental: At the chosen time, the mouse was decapitated and the brain was rapidly removed. The brain was weighed, then homogenized with 5 volumes of $0.1 \mathrm{~N} \mathrm{HCl}$. A sample of $2 \mathrm{ml}$ of brain homogenate or of $2 \mathrm{ml}$ of diluted plasma in a $50 \mathrm{ml}$ glass-stoppered centrifuge tube was mixed with $2 \mathrm{ml}$ of 1.5 м $\mathrm{NaH}_{2} \mathrm{PO}_{4}$ solution and $25 \mathrm{ml}$ of petroleum ether containing $1.5 \%$ isoamyl alcohol. After shaking for 45 minutes, $5 \mathrm{ml}$ of the solvent phasc was transferred to a counting vial containing $15 \mathrm{ml}$ of toluene scintillator. Radioactivity was determined in a liquid scintillation spectrometer. No significant quenching was observed. The percentage recoveries of total added 5 to 50 micrograms of ${ }^{35} \mathrm{~S}$-thiopental $\mathrm{Na}$ from the brain and plasma were $90 \pm 3 \%$ and $92 \pm 4 \%$, respectively.

Experimental procedure for the estimation of thiopental distribution between fat and protein: Minced fat pads, weighing about $100 \mathrm{mg}$, from epididymal adipose tissue of rats, were suspended in $1 \mathrm{ml}$ of Krebs-Ringer phosphate buffer, $\mathrm{pH} \mathrm{7.4,} \mathrm{with} 2 \%$ bovine serum albumin (Fraction $\mathrm{V}$ ). After a preincubation for 30 minutes at $20^{\circ} \mathrm{C}$, fat pads were incubated at $37^{\circ} \mathrm{C}$ for one hour with continuous shaking in air. At the beginning of the incubation time, $0.1 \mathrm{ml}$ each of $0.1 \%$ non-radioactive thiopental $\mathrm{Na}$ solution and the $\operatorname{drug}(s)$ solution to be tested was added. Thiopental in fat or medium was determined by the method of Brodie et al. (11). Distribution ratio was expressed as (concentration in fat)/(concentration in aqueous phase).

Determination of FFA: FFA released from fat pads into the incubation medium were determined by the method of Itaya and $\mathrm{Ui}$ (12).

Binding of thiopental by serum albumin: The extent of protein binding was estimated by the ultrafiltration method of Ohshika (13). After approximately one-tenth of albuminthiopental mixture solution was ultrafiltered under reduced pressure, the binding of thiopental by albumin was determined by comparing the concentration of the drug in the ultrafiltrate with that in the original solution.

\section{RESULTS}

\section{Prolongation of thiopental anesthesia}

The effect of epinephrine on the thiopental-induced sleep was shown in Table 1 and 2. It was found that epinephrine caused a dose-dependent increase of slceping time. At the $0.25 \mathrm{mg} / \mathrm{kg}$ dose level, epinephrine caused a four-fold increase of slceping time in mice and a three-fold increase in rats.

Tables 1 and 2 also showed the potentiating effect of sod. oleate on thiopental anesthesia, as compared with epinephrine. 
Table 1. Effect of epinephrine and sodium oleate on thiopental-induced anesthesia in mice.

\begin{tabular}{lcccc}
\hline \multicolumn{1}{c}{ Treatment } & Dose & $\begin{array}{c}\text { Sleeping time } \\
\text { (min) }\end{array}$ & $\%$ Prolongation \\
\hline None (5) & & - & $6 \pm 1.4$ & - \\
Epinephrine (5) & $0.1 \mathrm{mg} / \mathrm{kg}$ s.c. & $18 \pm 2.0^{* *}$ & 200 \\
Epinephrine (5) & $0.25 \mathrm{mg} / \mathrm{kg}$ s.c. & $24 \pm 3.8^{* *}$ & 300 \\
Sod. oleate (5) & $0.5 \mathrm{mmoles} / \mathrm{kg}$ i.p. & $13 \pm 3.5^{*}$ & 117 \\
Sod. olcate (5) & $1.0 \mathrm{mmole} / \mathrm{kg} \mathrm{i.p.}$ & $35 \pm 4.5^{* *}$ & 483 \\
\hline
\end{tabular}

Mice were pretreated with epinephrine or sod. oleate 20 minutes before i.p. injection of $55 \mathrm{mg} / \mathrm{kg}$ thiopental. Sodium oleate was suspended in saline just before use. Number of mice is in brackets.

: Means \pm S.E., Statistical difference from control : **P<0.01, $* \mathrm{P}<0.05$.

TABLE 2. Effect of epinephrine and sodium oleate on thiopental-induced anesthesia in rats.

\begin{tabular}{lcccc}
\hline \multicolumn{1}{c}{ Treatment } & Dose & $\begin{array}{c}\text { Sleeping time } \\
\text { (min) }\end{array}$ & $\%$ Prolongation \\
\cline { 2 - 3 } & & - & $18 \pm 2.0$ & - \\
Eone (5) & & $34 \pm 5.0^{* *}$ & 89 \\
Epinephrine (5) & $0.1 \mathrm{mg} / \mathrm{kg}$ s.c. & $55 \pm 6.5^{* *}$ & 206 \\
Sod. oleate (5) & $0.5 \mathrm{mmoles} / \mathrm{kg}$ i.p. & $30 \pm 4.5^{*}$ & 67 \\
Sod. oleate (5) & $1.0 \mathrm{mmole} / \mathrm{kg} \mathrm{i.p.}$ & $71 \pm 10.2^{* *}$ & 294 \\
\hline
\end{tabular}

Experimental conditions : See Tarle 1.

Statistical difference from control: **P<0.01, *P $\mathrm{P}<0.05$.

\section{Reduclion of anesthetic dose by epinephrine}

We found that non-treated mice were not anesthetized with doses less than $45 \mathrm{mg}$ / $\mathrm{kg}$ of thiopental which produced narcosis in $40 \%$ of the mice. And with doses of 50 and $55 \mathrm{mg} / \mathrm{kg}$, thiopental produced narcosis in $80 \%$ and $100 \%$ of the mice, respectively. Mice pretreated with $0.25 \mathrm{mg} / \mathrm{kg}$ of epinephrine hydrochloride twenty minutes before thiopental, were found to become sensitive to the drug; with doses of 40,45 and $50 \mathrm{mg}$ / $\mathrm{kg}$, thiopental produced narcosis in 40,80 and $100 \%$ of the treated mice, respectively.

3. Modification of thiopental entry into the brain

Monosodium salt of ${ }^{35} \mathrm{~S}$-thiopental was diluted with aqueous solution of non-labelled thiopental $\mathrm{Na}$ to give $1.4 \mu \mathrm{Ci} / \mathrm{mg}$. Injection was made intraperitoneally $(55 \mathrm{mg} / \mathrm{kg}$ ) or intravenously (40 mg/kg). Ten minutes after i.p. injection of thiopental, epinephrine or sod. oleate was administered intravenously to the mice. Although epinephrine was shown to increase the brain thiopental level at the $12 \mathrm{~min}$. period (Table 3), difference between the levels in controls and treated mice was statistically insignificant. On the contrary, sod. oleate showed a dramatic effect in increasing the brain thiopental level.

Since no apparent increase in brain thiopental level was found in mice received intravenous epinephrine, experiments were performed to ascertain if subcutaneous epinephrine would modify the brain thiopental level. The experimental conditions were as follows: mice were pretreated with subcutaneous injection of $0.25 \mathrm{mg} / \mathrm{kg}$ epinephrine 
TABLE 3. Effect of intravenous epinephrine or sodium oleate on the brain levels of ${ }^{35} \mathrm{~S}$-thiopental in mice.

\begin{tabular}{lcc}
\hline \multicolumn{1}{c}{ Treatment } & Dose & $\begin{array}{c}\text { Brain thiopental } \\
(\mu \mathrm{g} / \mathrm{g})\end{array}$ \\
\hline None (5) & - & $34.8 \pm 3.1$ \\
Epinephrine (4) & $0.1 \mathrm{mg} / \mathrm{kg}$ i.v. & $39.8 \pm 4.1$ \\
Sod. oleate (3) & $0.2 \mathrm{mmoles} / \mathrm{kg}$ i.v. & $62.9 \pm 6.3^{* *}$ \\
\hline
\end{tabular}

Epinephrine or sod. oleate was injected at 10 minutes after i.p. injection of $55 \mathrm{mg} / \mathrm{kg}{ }^{35} \mathrm{~S}$-thiopental. Mice were sacrificed at 12 minutes after thiopental. Number of mice is in brackets.

\$ : Mean \pm S.E.

Statistical difference from control : **P $<0.01$

TABLE 4. Effect of subcutaneous epinephrine or intraperitoneal sodium oleate on the brain level of ${ }^{35} \mathrm{~S}$-thiopental in mice.

\begin{tabular}{lcc}
\hline \multicolumn{1}{c}{ Treatment } & Dose & $\begin{array}{c}\text { Brain thiopental } \\
(\mu \mathrm{g} / \mathrm{g})\end{array}$ \\
\hline None (4) & - & $36.4 \pm 3.8$ \\
Epinephrine (4) & $0.25 \mathrm{mg} / \mathrm{kg}$ s.c. & $47.0 \pm 1.8^{*}$ \\
Sod, oleate (4) & $\mathbf{0 . 5}$ mmoles/kg i.p. & $40.3 \pm 1.8$ \\
\hline
\end{tabular}

Mice were pretreated with epinephrine or sod. oleate at 20 minutes before i.v. injection of $40 \mathrm{mg} / \mathrm{kg}{ }^{35} \mathrm{~S}$-thiopental. Mice were sacrificed at 5 minutes after thiopental. Number of mice is in brackets.

* : Means \pm S.E.

Statistical difference from control : *P<0.05

TABLE 5. Effect of subcutaneous epinephrine on the brain- and plasma-levels of ${ }^{35} \mathrm{~S}$-thiopental in rats.

\begin{tabular}{|c|c|c|c|}
\hline \multirow{2}{*}{ Treatment } & \multirow{2}{*}{ Dose } & \multicolumn{2}{|c|}{ Thiopental } \\
\hline & & Brain $(\mu \mathrm{g} / \mathrm{g})$ & Plasma $(\mu \mathrm{g} / \mathrm{m} 1)$ \\
\hline None (4) & - & $32.9 \pm 5.6$ & $44.7 \pm 3.3$ \\
\hline Epinephrine (4) & $0.25 \mathrm{mg} / \mathrm{kg}$ s.c. & $42.0 \pm 4.5$ & $46.3 \pm 2.7$ \\
\hline
\end{tabular}

Experimental conditions : See TABLe 4.

or i.p. injection of $0.5 \mathrm{mmoles} / \mathrm{kg}$ sod. oleate and twenty minutes later the mice received intravenous thiopental.

As shown in Table 4, the brain thiopental levels in epinephrine-treated mice were significantly higher than those in controls. However, no significant increase was found in sod. oleate-treated mice.

Table 5 also shows the effect of epinephrine on the brain- and plasma-levels of thiopental in rats. The brain thiopental levels of treated rats were much higher than those of controls, while the plasma levels remained essentially unchanged. These data strongly suggest that epinephrine may augment the thiopental penetration into the brain by making more unbound thiopental in the plasma.

4. In vitro distribution of thiopental between fat and protein

When $100 \mu \mathrm{g}$ of thiopental was added to the incubation mixture composed of fat 
pads and albumin solution, the total amount taken up by $100 \mathrm{mg}$ fat tissue at one hour incubation period, was $44.1 \pm 2.6 \mu \mathrm{g}$. If this value is expressed in terms of distribution ratio between fat and protcin, the ratio is $7.9 \pm 0.5$.

In concentrations from $10^{-7} \mathrm{M}$ to $10^{-6} \mathrm{M}$, epinephrine had no effect on the distribution ratio. Epinephrine at a final concentration of $10^{-5} \mathrm{M}$ was found to cause a significant increase in the ratio (Table 6). It will be noted that, under such conditions, epinephrine has a property of mobilizing thiopental from the albumin to the lipid phase.

However, the question was raised whether the epinephrine effect was limited solely to either lipid or albumin, or whether epinephrine would affect both of them. In order to ascertain the direct effect of the drug on the adipose tissue, albumin-free Krebs-Ringer solution was used as medium source. As shown in Table 6, epinephrine no longer exerted its thiopental-mobilizing effect under such experimental conditions.

TABLE 6. Effect of epinephrine on the distribution ratio for thiopental in systems of fat : albumin and fat : Ringer solution.

\begin{tabular}{ccc}
\hline \multirow{2}{*}{ Epinephrine (M) } & \multicolumn{2}{c}{ Distribution ratio } \\
\cline { 2 - 3 } & Fat : Albumin & Fat : Ringer \\
\hline None (8) & $7.9 \pm 0.5$ & $27.0 \pm 2.2$ \\
$1 \times 10^{-6}(5)$ & $8.2 \pm 0.5$ & $26.8 \pm 2.4$ \\
$1 \times 10^{-5}(8)$ & $12.8 \pm 1.1^{*}$ & $29.5 \pm 2.4$ \\
$1 \times 10^{-4}(6)$ & $14.0 \pm 1.5^{*}$ & - \\
\hline
\end{tabular}

\footnotetext{
Experimental procedures are described under Materials añd Metions. Number of experiments is in brackets.

Statistical difference from control : $* \mathrm{P}<0.05$.
}

Secondly, the direct effect of epinephrinc on the binding of thiopental to serum albumin was investigated. After one-hour incubation of thiopental in Krebs-Ringer phosphate buffer $(\mathrm{pH} 7.4$ ) containing $2 \%$ albumin, at room temperature, with or without epinephrine $10^{-5} \mathrm{M}$, the binding of thiopental was determined. The percentage bindings of thiopental in the controls and epinephrine-added samples were $77.3 \pm 1.1 \%$ and 76.7 $\pm 4.0 \%$, respectively.

These results provided evidence for the view, that both lipid and albumin are required for the manifestation of the epinephrine effect.

5. Correlation between release of FFA and penetration of thiopental from and into the adipose tissue

It is well known that an incubation of epinephrine with rat adipose tissue stimulates the formation of FFA and the acids formed can easily be released from the tissue so long as albumin is added to the incubation medium as the acids-receptor (14).

Therefore, it seemed of interest to see if the FFA mobilization is associated with the epinephrine-induced acceleration of thiopental penetration into the adipose tissue. As compared with the natural release, epinephrine in concentrations of $10^{-7} \mathrm{M}$ and $10^{-6} \mathrm{M}$ caused about two-fold increase in FFA release. However, there was no increased uptake of thiopental by the tissue. 
TABLE 7. Correlation between release of FFA from fat and distribution ratio for thiopental in fat : albumin system.

\begin{tabular}{|c|c|c|}
\hline Addition & $\begin{array}{c}\text { FFA released } \\
(\mu \mathrm{eq} / \mathrm{ml} \text { medium } / \mathrm{hr})\end{array}$ & Distribution ratio \\
\hline None (6) & $0.24 \pm 0.02$ & $7.8 \pm 0.8$ \\
\hline Epinephrine $\left(10^{-5} M\right)$ & $0.71 \pm 0.10$ & $13.0 \pm 1.2^{* *}$ \\
\hline $\begin{array}{l}\text { Epinephrine }\left(10^{-5} \mathrm{M}\right)+ \\
\text { Propranolol }\left(10^{-4} \mathrm{M}\right)\end{array}$ & $0.26 \pm 0.03$ & $9.2 \pm 1.0$ \\
\hline Propranolol $\left(10^{-4} \mathrm{M}\right)(4)$ & $0.18 \pm 0.04$ & $7.5 \pm 0.8$ \\
\hline
\end{tabular}

Number of experiments is in brackets.

Statistical difference from control: ${ }^{* *} \mathrm{P}<0.01$.

When the concentration of epinephrine was raised to $10^{-5} \mathrm{M}$, there was a three-fold increase in FFA release and simultaneously there occurred a significant increase in thiopental uptake by the tissue (Table 7). Propranolol $\left(10^{-4} \mathrm{M}\right)$ effectively antagonized the action of epinephrine on both lipolysis and thiopental uptake.

To provide further understanding of the relation of lipolysis to thiopental uptake, FFA were externally added to the incubation medium to study their effect on thiopental uptake. As shown in Table 8 , sod. oleate in concentrations more than $1 \mu \mathrm{eq} / \mathrm{ml}$ medium caused an increase in thiopental uptake by the tissue.

From these results, it seemed likely that the epinephrine effcct in increasing thiopental uptake resulted from a stimulation of lipolysis.

\section{DISCUSSION}

In the present studies, potentiation by epinephrine of thiopental anesthesia was evaluated by two methods as follows: 1) prolongation of thiopental anesthesia by pretreatment of animals with epinephrine; 2) reduction of the anesthetic dose by prior administration of epinephrine. The results obtained have reconfirmed and extended earlier observations by Lamson et al. (1) that epinephrine was extremely effective in potentiating the barbiturate anesthesia.

It is obvious that the potentiating effect of epinephrine is attributed to an increase in thiopental entry into the brain. However, there was a time lag in onset of the epinephrine effect. Under condition in which the brain thiopental level was determined immediately after intravenous administration of epinephrine, no apparent difference between control and treated mice was observed.

Thereforc, pstentiating action of epinephrine on the thiopental anesthesia is not likely related to its hypertensive effect but to its metabolic cffect. As far as the time 
in onset of potentiating action is concerned, epinephrine makes a sharp contrast with fatty acids, the potentiating action of the latter being direct and rapid in onset.

There is enough evidence to suggest that thiopental is strongly bound to serum albumin but in turn is displaced by a number of acidic substances including fatty acids (15, 16). Therefore, if a substance that is capable of displacing thiopental from serum albumin is injected to animal, this may cause potentiation of thiopental anesthesia by making more unbound thiopental diffusible into the brain.

This explanation holds good with the potentiation of barbiturate ancsthesia by detergents (16) or by iodinated benzoic acid derivatives (17). Increased penetration of thiopental by sod. oleate which was shown in the present study may also be explained by this mode of action.

It has already been shown that epinephrine stimulates lipolysis in vivo $(18,19)$ as well as in vitro (14). The present in vitro experiment indicates that epinephrine is capable of altering the ratio of thiopental distribution between fat and protein and that this alteration is closely correlated to epinephrine-induced lipolysis. Furthermore, there was a striking similarity between effects of epinephrine and of externally added oleate on the thiopental uptake by adipose tissue. It is very likely that epinephrine alters the distribution ratio through its lipolytic action. If it were true, a causal sequence involved in this process may be considered as follows: epinephrine stimulates the release of FFA from adipose tissue; secondly, the released FFA displace thiopental from its binding sites on serum albumin; thiopental thus displaced enters into adipose tissue because of its high lipid solubility.

These interpretations are only conjectural. It will be necessary to carry out kinetic studies with thiopental-FFA interaction at binding sites on serum albumin.

It is well known that epinephrine produces an abrupt increase in plasma FFA level when injected to animals (20). If epinephrine-treated animal would receive intravenous thiopental, binding of thiopental to plasma albumin may be inhibited by the elevated plasma level of FFA, thereby increasing the penetration of the drug into the brain. The present studies strongly suggest an important role of plasma FFA level as one of the physiological variables in deciding the depth and duration of thiopental anesthesia and also indicate that epinephrine may potentiate the anesthesia through its lipolytic action.

\section{SUMMARY}

1. Potentiating effect of epinephrine on the thiopental anesthesia was studied by comparison with that of sodium oleate.

2. Potentiation of the anesthesia by epinephrine was found to be due to an increased penctration of thiopental into the brain.

3. Penetration of thiopental into epididymal adipose tissue was studied in vitro. Epinephrine was shown to produce a significant increase in thiopental penetration. A close correlation was found between the release of FF $\Lambda$ from adipose tissue and the penetration of thiopental into the tissue. It was also found that sodium oleate in medium 
concentration as low as $1,0 \mu \mathrm{eq} / \mathrm{ml}$ is capable of mobilizing thiopental to adipose tissue.

4. The pharmacological significance of penetration studies has been discussed in relation to the present findings.

\section{REFERENCES}

1) Lamson, P.D., Greig, M.E. And Williams, L.: J. Pharmac. exp. Ther, 106, 219 (1952)

2) MrLosévié, M.P. : Atchs int. Pharmacodyn. Thér. 106, 437 (1956)

3) Koga, K., Mrzugucin, T., Ohmiya, Y. and NakaI, K.: Jap. J. Pharmac. 17, 328 (1967)

4) Mazet, P. ANd Bush, M.T.: Biochem. Pharmac, 18, 597 (1969)

5) OHshikA, H.: Folia pharmac. jap. 64, $92 \$$ (1968)

6) Brodie, B.B.: Proc. Roy. Soc. Med. 58, 946 (1965)

7) Solomon, H.M., Schrogie, J.J. And Williams, D.: Biochem. Pharmac. 17, 143 (1963)

8) Anton, A.: J. Pharmac. exp. Ther. 134, 291 (1961)

9) Gordon, R.S. JR. and Cherkes, A.: Proc. Soc. exp. Biol. Med. 97, 150 (1958)

10) Lopez, E., White, J.E. and Engel, F.L.: J. biol. Chem. 234, 2254 (1959)

11) Brodie, B.B., Burns, J.J., Mark, L.C., Life, R.A. Bernstrin, E. and Papper, E.M.: J. Pharmac. exp. Ther. 109, 26 (1953)

12) I'tAYA, K. AND U, M.: J. Lipid Res. 6, 16 (1965)

13) OHshiKA, H.: Folia pharmac. jap. 63, 57 (1967)

14) White, J.E. and Engel, F.L.: Proc. Soc. exp. Biol. Med. 99, 375 (1958)

15) Nakai, K. ANd OhmiYa, Y.: Folia pharmac. jap. 64, $2 \$(1968)$

16) Goldbaum, L.R. And Smith, P.K.: J. Pharmac. exp. Ther, 111, 197 (1954)

17) Lasser, E.C. Elizondo-Martel, G. and Granke, R.C.: Anesthesiology 24, 665 (1963)

18) Dole, V.P.: J. clin. Invest. 35, 150 (1956)

19) Sahafrir, E. ANd Steinberg, D.: J. clin. Invest. 39, 310 (1960)

20) Havel, R.J.: Lipid Pharmacology, Edited by PAoletri, R., p. 357, Academic Press, Inc., New York (1964) 